\title{
A STUDY OF THE EFFICIENCY OF CULTURE MEDIA FOR THE RECOVERY OF LYOPHILIZED PATHOGENIC BACTERIA
}

\author{
V. O. USHKALOV, Doctor of Veterinary Sciences, Professor \\ https://orcid.org/0000-0001-5694-632X \\ E-mail:ushkalov63@gmail.com
}

Ukrainian Laboratory of Quality and Safety of Agricultural Products of the National University of Life and Environmental Sciences of Ukraine, Kyiv, Ukraine

L. M. VYGOVSKA, Doctor of Veterinary Sciences, Research Fellow

https://orcid.org/0000-0001-6745-5753

E-mail:Invygovska@gmail.com

Ukrainian Laboratory of Quality and Safety of Agricultural Products of the National University of Life and Environmental Sciences of Ukraine, Kyiv, Ukraine

A. V. USHKALOV, Candidate of Veterinary Sciences https://orcid.org/0000-0001-8317-7909

E-mail:vetdocman@gmail.com

Main Administration of State Service of Ukraine on Food Safety and Consumer Protection in Kharkiv region, Kharkiv, Ukraine

S. O. BOIANOVSKYI, Junior Research Fellow https://orcid.org/ 0000-0002-4621-5192

E-mail: sboyanka@gmail.com

Ukrainian Laboratory of Quality and Safety of Agricultural Products of the National University of Life and Environmental Sciences of Ukraine, Kyiv, Ukraine

A. V. HRANAT, Junior Research Fellow https://orcid.org/0000-0003-3273-903X

E-mail: andriy.hranat@gmail.com

Ukrainian Laboratory of Quality and Safety of Agricultural Products of the National University of Life and Environmental Sciences of Ukraine, Kyiv, Ukraine

S. A. TERESHCHENKO, Junior Research Fellow https://orcid.org/0000-0002-5786-8711

E-mail:kelas1993@gmail.com

Ukrainian Laboratory of Quality and Safety of Agricultural Products of the National University of Life and Environmental Sciences of Ukraine, Kyiv, Ukraine

L. O. DAVYDOVSKA, Engineer of the 3rd category

E-mail: li.davydovskaya@gmail.com

Ukrainian Laboratory of Quality and Safety of Agricultural Products of the National University of Life and Environmental Sciences of Ukraine, Kyiv, Ukraine 
Yu. Yu. VISHOVAN, Junior Research Fellow https://orcid.org/0000-0003-1128-593X

Ukrainian Laboratory of Quality and Safety of Agricultural Products of the National University of Life and Environmental Sciences of Ukraine, Kyiv, Ukraine E-mail: anatomi1991@gmail.com

\begin{abstract}
Today, the most appropriate way of long-term storage of most microorganism strains in collections is their lyophilization. The rate and quality of the recovery of biological properties in lyophilized bacterial cultures depend on the quality of culture media used for this purpose. The purpose of this study was to investigate the effectiveness of culture media for the recovery of lyophilized pathogenic bacteria.

The strains of Salmonella typhimurium, Pasteurella multocida, Yersinia pseudotuberculosis, and Staphylococcus aureus from the collection of the Ukrainian Laboratory of Quality and Safety of Agricultural Products of the National University of Life and Environmental Sciences of Ukraine were used in the study. In order to restore lyophilized bacterial cultures, several variants of culture media were used: meat-peptone broth (Pharmactive, Ukraine) with the addition of 5\% equine serum and $0.5 \%$ glucose; meat-peptone broth (Pharmactive, Ukraine) with the addition of $5 \%$ bovine serum and $0.5 \%$ glucose; meat-peptone broth (Pharmactive, Ukraine) with the addition of $5 \%$ bovine serum and $0.5 \%$ glucose; brain-heart infusion broth (HiMedia, India) and tryptone soya broth (HiMedia, India). Faibich protective medium was used as a cryoprotectant. It was found that in the process of sublimation and cryopreservation of cultures of Salmonella typhimurium, Pasteurella multocida, Yersinia pseudotuberculosis, and Staphylococcus aureus, the loss of viable microbial cells was 99.91-99.98\%. The concentration of viable microbial cells in lyophilized cultures of Salmonella typhimurium, Pasteurella multocida, Yersinia pseudotuberculosis, Staphylococcus aureus was recorded in the range of $1.4 \times 10^{4}-1.7 \times 10^{6} \mathrm{CFU} / \mathrm{cm}^{3}$. During a single passage on different culture media, obtained biomass of the studied cultures was in the initial titer $x \times 10^{9}$. The highest productivity in recovered cultures was obtained using brain-heart infusion broth manufactured by HiMedia, India (concentration of live microbial cells in experimental cultures was recorded in the range of 5.7-6.4 $\times 10^{9} \mathrm{CFU} / \mathrm{cm}^{3}$ ).
\end{abstract}

Keywords: Salmonella, Pasteurella, Yersinia, Staphylococcus, nutrient media, lyophilization

\section{Introduction}

In order to preserve the activity of microorganism strains, several main methods are used: lyophilization, cryopreservation, freezing of agar media grown bacterial cultures at $-70^{\circ} \mathrm{C}$, periodic reseeding on nutrient media, cultivation in appropriate biological systems (chicken embryos, cell culture, etc.) (Cherkasskiy et al., 1988; Osadchaya et al., 2002; Holovko et al., 2004; Akymenko, 2007; Vygovska et al., 2007; Ushkalov et al., 2009).

To date, the most appropriate way of long-term storage of most microorganism strains in collections is their lyophilization (Akymenko, 2007; Vygov- 
ska et al., 2007). For cryopreservation and subsequent freeze-drying, it is recommended to use cells in the stationary phase of growth, when the highest level of bacterial accumulation is reached, the intensity of metabolic processes decreases, there is an increase in cell resistance to freezing and drying (Vygovska et al., 2007; Vyigovskaya et al., 2008).

The choice of a protective suspension medium is important for effective lyophilization. Colloidal solutions are used for this purpose. The components of the suspension protective media, as a rule, introduce substances that reduce the crystallization point of water; this prolongs the cooling time of the cells and creates conditions for minimizing the negative effects of ice crystals, as well as in some way provides a protective effect during freeze-drying (Emtsova et al., 1991; Osadchaya et al., 2002; Akymenko, 2007; Romanko, 2010; Hordiienko et al., 2011; Romanko et al., 2012; Holovko et al., 2015; Hordiienko et al., 2018).

For bacteria, cryopreservation and subsequent freeze-drying under vacuum are stressors that affect the cell due to increased osmotic pressure, temperature shock, changes in intracellular $\mathrm{pH}$, high salt concentration. They lead to the accumulation of non-lethal and lethal damage to the structures (cells) of the biological object (Osadchaya et al., 2002; Holovko et al., 2004; Romanko et al., 2006; Vygovska et al., 2007; Ushkalov et al., 2008; Hordiienko et al., 2011).

Non-lethal damage and the resulting changes in the properties of bacterial cultures are usually reversible and are restored to normal under appropriate conditions and with the use of certain methods. The rate and quality of the recovery of biological properties in lyophilized bacterial culture depend on the quality of culture media used for this purpose. Some au- thors recommend adding specific components to the culture media intended for the cultivation and recovery of certain microorganism species (Ushkalov et al., 2008; Kovtun et al., 2013; Holovko et al., 2015). The effectiveness of the used culture media determined by comparing the biological properties of bacterial cultures at the stage of laying for long-term storage, after lyophilization of the culture, and after its recovery in the appropriate culture medium (Postoienko et al., 2011; Hordiienko et al., 2011; Kovtun et al., 2013; Holovko et al., 2015).

Purpose. To investigate the effectiveness of culture media for the recovery of lyophilized pathogenic bacteria.

\section{Materials and methods of research}

The Salmonella typhimurium, Pasteurella multocida, Yersinia pseudotuberculosis, Staphylococcus aureus strains from the collection of Ukrainian Laboratory of Quality and Safety of Agricultural Products of the National University of Life and Environmental Sciences of Ukraine (ULQSAP of NUBiP) isolated during microbiological studies of pathological material from animals in the research department of ULQSAP of NUBiP of Ukraine, were used in the study.

Cultural and protective media were prepared and controlled in accordance with ISO 11133:2014 "Microbiology of food, animal feed and water. Preparation, production, storage and performance testing of culture media".

Faibich protective medium was used as a cryoprotectant (gelatin $-1.0 \%$, sucrose $-10.0 \%$, distilled water $-89 \%$ ) in a ratio of $1: 1$ with the broth of 24hour cultures of Salmonella typhimurium, Pasteurella multocida, and Staphylococcus aureus. Each test culture 
was packaged $1.0 \mathrm{~cm}^{3}$ into $5 \mathrm{~cm}^{3}$ vials. Before lyophilization (cryopreservation and subsequent sublimation), three vials were taken from each experimental batch to determine the typicality, homogeneity, and concentration of bacterial mass in the suspension $\left(\mathrm{CFU} / \mathrm{cm}^{3}\right)$. Cryopreservation of cultures was carried out in a freezer Forma 700 Series Thermo Scientific (USA) at $-70^{\circ} \mathrm{C}$.

Sublimation drying was performed in an LP-3 apparatus from TelStar (Spain) with a deep vacuum of $0.17 \mathrm{mB}$ and a condenser temperature of $45-50{ }^{\circ} \mathrm{C}$. After lyophilization, the typicality, homogeneity, and concentration of viable microbial cells $\left(\mathrm{CFU} / \mathrm{cm}^{3}\right)$ were determined in the experimental samples. In order to establish the concentration of viable microorganisms, samples were prepared in accordance with ISO 68871:2003 "Microbiology of food and an- imal feeding stuffs. Preparation of test samples, initial suspension and decimal dilutions for microbiological examination. Part 1. General rules for the preparation of the initial suspension and decimal dilutions".

The biological properties of the studied strains were determined before lyophilization and in cultures recovered on different nutrient media. The studies were performed according to ISO 6888-1:1999/ Amd 1:2003 "Microbiology of food and animal feeding stuffs - Horizontal method for the enumeration of coagulase-positive staphylococci (Staphylococcus aureus and other species) - Part 1: Technique using Baird-Parker agar medium; EN 12824:1997 • Standard Details • Microbiology of food and animal feeding stuffs - Horizontal method for the detection of Salmonella"; Metodychni rekomendatsii z diahnostyky, profilaktyky ta zakhodiv

\section{Culture media for bacterial cultures}

\begin{tabular}{|l|c|c|}
\hline \multicolumn{1}{|c|}{ Strain } & Nutrient media & Manufacturer \\
\hline \multirow{4}{*}{$\begin{array}{l}\text { Salmonella } \\
\text { typhimurium }\end{array}$} & Meat-peptone broth (MPB) & $\begin{array}{c}\text { Pharmactive, } \\
\text { Ukraine }\end{array}$ \\
\cline { 2 - 3 } & Brain-hearth infusion broth (BHIB) & HiMedia(India) \\
\cline { 2 - 3 } & Tryptone soya broth (TSB) & HiMedia (India) \\
\hline \multirow{4}{*}{$\begin{array}{l}\text { Pasteurella } \\
\text { multocida }\end{array}$} & $\begin{array}{c}\text { MPB culture media with the addition of 5\% equine } \\
\text { serum and 0.5\% glucose }\end{array}$ & $\begin{array}{c}\text { Pharmactive, } \\
\text { Ukraine }\end{array}$ \\
\cline { 2 - 3 } & $\begin{array}{c}\text { MPB with the addition of 5\% bovine serum and } \\
0.5 \% \text { glucose }\end{array}$ & $\begin{array}{c}\text { Pharmactive, } \\
\text { Ukraine }\end{array}$ \\
\cline { 2 - 3 } & Brain-hearth infusion broth & HiMedia (India) \\
\cline { 2 - 3 } $\begin{array}{l}\text { Yersinia pseudo- } \\
\text { tuberculosis }\end{array}$ & Tryptone soya broth & HiMedia (India) \\
\cline { 2 - 3 } & Meat-peptone broth & $\begin{array}{c}\text { Pharmactive, } \\
\text { Ukraine }\end{array}$ \\
\cline { 2 - 3 } & Brain-hearth infusion broth & HiMedia (India) \\
\hline \multirow{4}{*}{$\begin{array}{l}\text { Staphylococcus } \\
\text { aureus }\end{array}$} & Tryptone soya broth & HiMedia (India) \\
\cline { 2 - 3 } & $\begin{array}{c}\text { MPB with the addition of } 5 \% \text { bovine serum and } \\
0.5 \% \text { glucose }\end{array}$ & $\begin{array}{c}\text { Pharmactive, } \\
\text { Ukraine }\end{array}$ \\
\cline { 2 - 3 } & Tryptone soya broth & HiMraine \\
\cline { 2 - 3 } & Brain-hearth infusion broth & HiMedia (India) \\
\hline
\end{tabular}


borotby z pasterelozom (kholeroiu) ptytsi. (Stehnii et al., 2009); Metodicheskie ukazaniya «Epidemiologicheskiy nadzor i profilaktika psevdotuberkuleza i kishechnogo iersinioza» (2009).

In order to restore lyophilized bacterial cultures, several variants of culture media were used (Table 1).

\section{Results of the research and their discussion}

At the beginning of the experiment, the studied culture biological properties of the matrix broods of Salmonella typhimurium, Pasteurella multocida, Yersinia pseudotuberculosis, Staphylococcus aureus were determined (Table 2).

The studied cultures were characterized by population homogeneity and corresponding for each species typicality by morphological, cultural, and biochemical properties.

Culture of S. typhimurium on bismuth sulfite agar (BSA) medium (Pharmactive, Ukraine) formed black S-shaped colonies with a metallic luster, rounded, regular shape, 3-4 $\mathrm{mm}$ in diameter, the color of the medium around the colonies became black-gray. S. typhimurium fermented (with the formation of acid and gas) glucose, arabinose, mannitol, maltose, sorbitol, dulcite; reduced nitrates to nitrites, isolated $\mathrm{H}_{2} \mathrm{~S}$. The culture of $S$. typhimurium was agglutinated with O-complex sera 1,2 and monoreceptor $\mathrm{H}$-agglutinating serum of the 1 st phase and the 2nd phase - 1, 2, 5, 6 .

Culture of $Y$. pseudotuberculosis on plate count agar medium (HiMedia, India) formed R-colonies at a temperature of 37 ${ }^{\circ} \mathrm{C}$, diameter 3-4 mm, large, irregularly shaped, with uneven edges, hilly, opaque, greenish-cream color, esculin, fermented glucose, $\alpha$-arabinose, mannose, xylose, rhamnose, maltose, mannitol.

The culture of $P$. multocida on plate count agar medium (HiMedia, India) formed homogeneous S-colonies with a diameter of $0.7-1.2 \mathrm{~mm}$, rounded, convex, shiny, with a smooth clear edge, milky white, translucent; fermented with the formation of acid without sugar: glucose, mannitol, sucrose.

\section{Biological properties of the studied cultures (matrix cultivation)}

\begin{tabular}{|c|c|c|c|c|}
\hline $\begin{array}{l}\text { Determined indicator } \\
\qquad(\mathrm{n}=5)\end{array}$ & $\begin{array}{l}\text { Salmonella typh- } \\
\text { imurium }\end{array}$ & $\begin{array}{l}\text { Yersinia pseudotuber- } \\
\text { culosis }\end{array}$ & $\begin{array}{l}\text { Pasteurella mul- } \\
\text { tocida }\end{array}$ & $\begin{array}{c}\text { Staphylococcus } \\
\text { aureus }\end{array}$ \\
\hline $\begin{array}{l}\text { Concentration of } \\
\text { viable broth bacteria } \\
(\mathrm{MPB}), \mathrm{CFU} / \mathrm{cm}^{3}\end{array}$ & $4.5 \times 10^{9}$ & $2.8 \times 10^{9}$ & $1.6 \times 10^{9}$ & $6.6 \times 10^{9}$ \\
\hline $\begin{array}{l}\text { Concentration of via- } \\
\text { ble cells (broth culture } \\
+ \text { protective medium, } \\
1: 1), \mathrm{CFU} / \mathrm{cm}^{3}\end{array}$ & $2.1 \times 10^{9}$ & $1.4 \times 10^{9}$ & $0.9 \times 10^{9}$ & $3.3 \times 10^{9}$ \\
\hline $\begin{array}{l}\text { Typical growth on } \\
\text { solid nutrient media }\end{array}$ & $\begin{array}{l}\text { Typical of the } \\
\text { species }\end{array}$ & Typical of the species & $\begin{array}{l}\text { Typical of the } \\
\text { species }\end{array}$ & $\begin{array}{l}\text { Typical of the } \\
\text { species }\end{array}$ \\
\hline $\begin{array}{l}\text { Homogeneity of the } \\
\text { microorganism pop- } \\
\text { ulation }\end{array}$ & $\begin{array}{l}\text { Homogeneous } \\
\text { gram-negative } \\
\text { rods in size } \\
2-4 \times 0.5-0.8 \mu \mathrm{m}\end{array}$ & $\begin{array}{c}\text { Homogeneous } \\
\text { gram-negative cocci } \\
\text { and ovoids, } 0.8-1.2 \times \\
0.5-0.8 \mu \mathrm{m} \text { in size, mo- } \\
\text { bile at } 23^{\circ} \mathrm{C} \text {, immobile } \\
\text { at } 37^{\circ} \mathrm{C}\end{array}$ & $\begin{array}{c}\text { Homogeneous } \\
\text { small gram-neg- } \\
\text { ative } \\
\text { ovoids, size } \\
0.5-1 \text { x } 0.5-0.8 \\
\mu \mathrm{m}\end{array}$ & $\begin{array}{c}\text { Homogeneous } \\
\text { gram-positive } \\
\text { cocci, size } \\
1.0-1 \times 1.5-2.0 \\
\mu \mathrm{m}\end{array}$ \\
\hline Biochemical properties & $\begin{array}{l}\text { Typical for the } \\
\text { species }\end{array}$ & Typical for the species & $\begin{array}{l}\text { Typical for the } \\
\text { species }\end{array}$ & $\begin{array}{l}\text { Typical for the } \\
\text { species }\end{array}$ \\
\hline
\end{tabular}




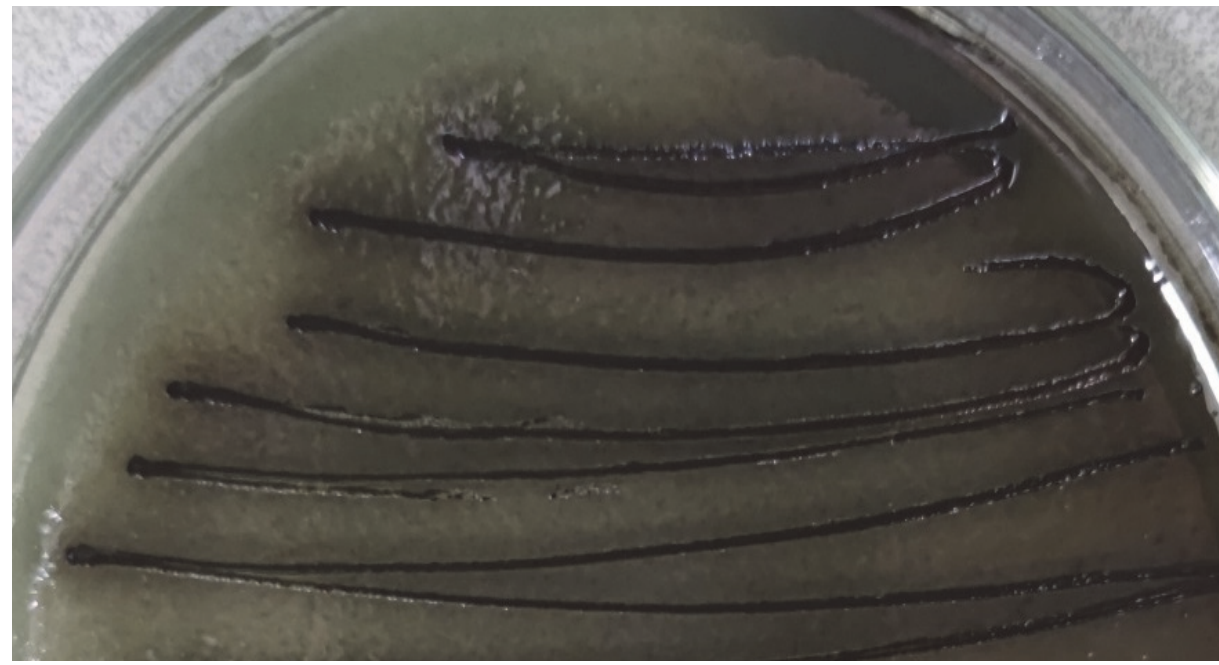

Fig. 1. Culture of S. typhimurium on bismuth sulfite agar (BSA) medium (Pharmactive, Ukraine)

Culture of $S$. aureus on Baird-Parker Agar medium (HiMedia, India) formed S-colonies, 1-2 mm in diameter, black, shiny, surrounded by a zone of enlightenment (lecithinase activity); coagulated rabbit plasma, fermented to form mannitol acid, glucose.
The studied cultures were lyophilized. Viability was determined in lyophilized cultures: population homogeneity, growth typicality on solid nutrient media and concentration of viable cells. The research results are shown in Table 3.

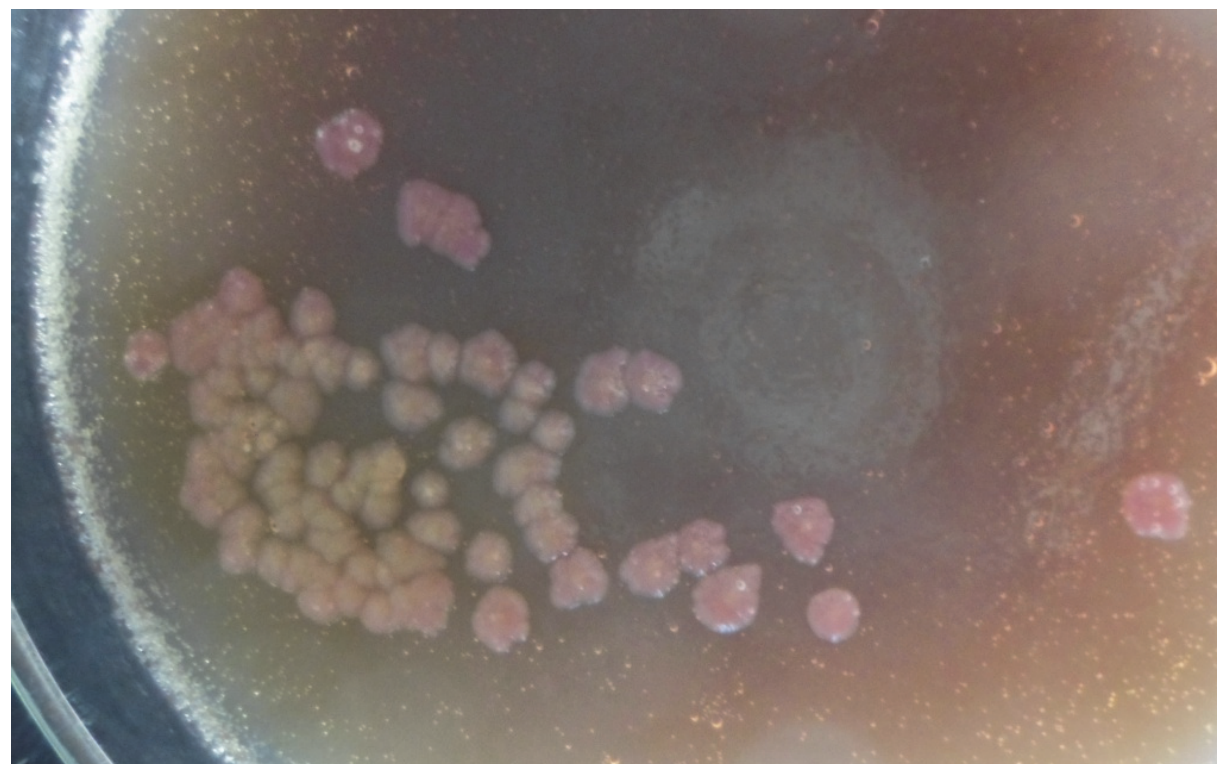

Fig. 2. Culture of Y. pseudotuberculosis R-colonies at a temperature of $37^{\circ} \mathrm{C}$ on Yersinia isolation agar (HiMedia, India) 


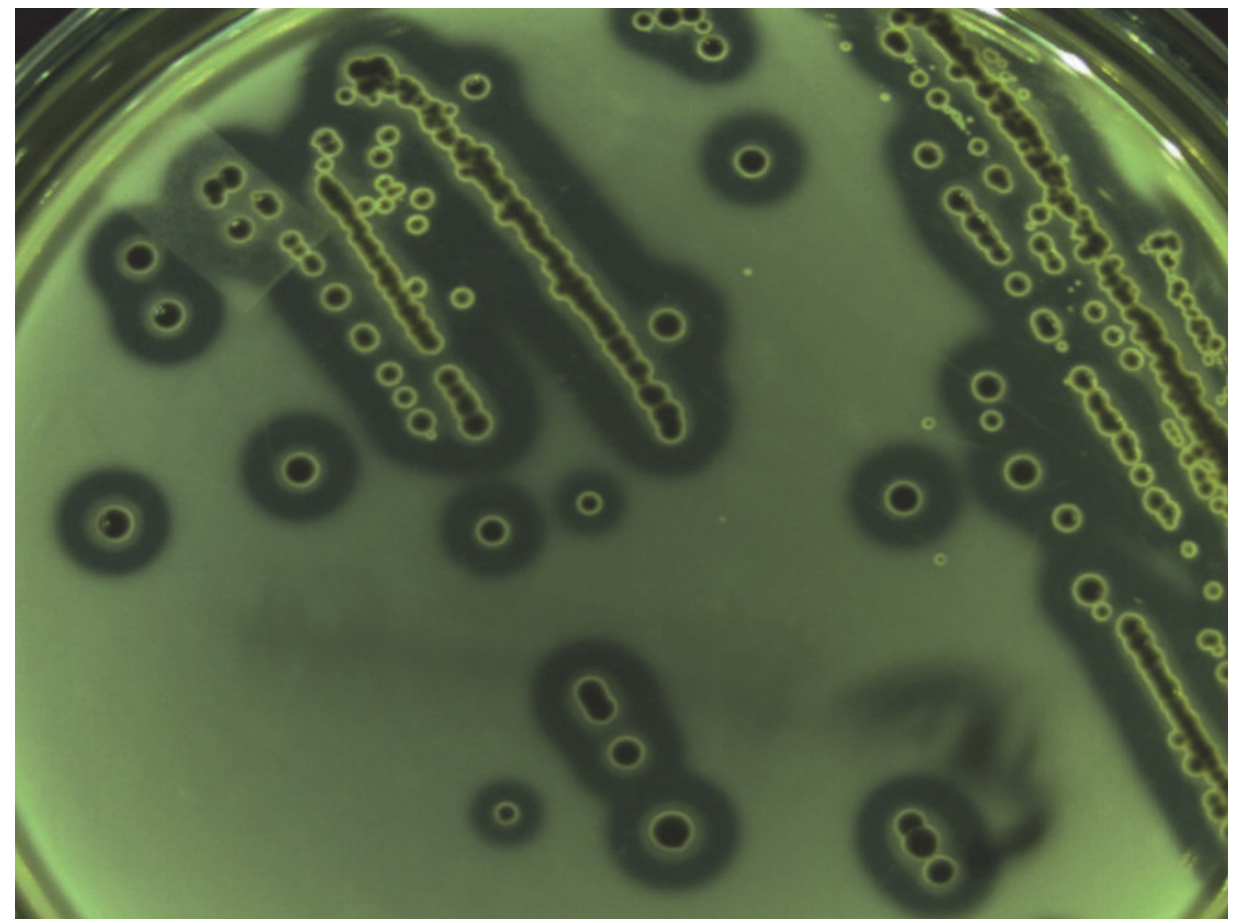

Fig. 3. Culture of S. aureus on Baird-Parker agar medium (HiMedia, India)

It was found that cultures subjected to lyophilization had a changed morphology: in smears of rehydrated lyophilizates of S. typhimurium, Y. pseudotuberculosis, $P$. multocida cultures recorded small polymorphic gram-negative structures: ovoids, rods; in smears of $S$. aureus small gram-positive cocci, ovoids. On solid nutrient media after the appropriate incubation period, the rehydrated cultures formed colonies typical for the respective species of microorganisms. There was a significant decrease in the concentration of viable microbial cells in cultures after lyophilization. Thus, the concentration of viable microbes in

\section{Viability of lyophilized cultures}

\begin{tabular}{|l|c|c|c|c|}
\hline $\begin{array}{c}\text { Determined indi- } \\
\text { cator }(\mathrm{n}=5)\end{array}$ & $\begin{array}{c}\text { Salmonella } \\
\text { typhimurium }\end{array}$ & $\begin{array}{c}\text { Yersinia pseudo- } \\
\text { tuberculosis }\end{array}$ & $\begin{array}{c}\text { Pasteurella } \\
\text { multocida }\end{array}$ & $\begin{array}{c}\text { Salmonella } \\
\text { typhimurium }\end{array}$ \\
\hline $\begin{array}{l}\text { Concentration } \\
\text { of viable cells } \\
\text { after lyophiliza- } \\
\text { tion, CFU/cm }\end{array}$ & $1.9 \times 10^{5}$ & $1.8 \times 10^{4}$ & $1.4 \times 10^{4}$ & $1.7 \times 10^{6}$ \\
\hline $\begin{array}{l}\text { Homogeneity } \\
\text { of the } \\
\text { microorganism } \\
\text { population }\end{array}$ & $\begin{array}{c}\text { Small polymor- } \\
\text { phic gram-neg- } \\
\text { ative structures: } \\
\text { ovoids, rods }\end{array}$ & $\begin{array}{c}\text { Small polymor- } \\
\text { phic gram-neg- } \\
\text { ative structures: } \\
\text { ovoids, rods }\end{array}$ & $\begin{array}{c}\text { Small polymor- } \\
\text { phic gram-neg- } \\
\text { ative structures: } \\
\text { ovoids, rods }\end{array}$ & $\begin{array}{c}\text { Small gram-pos- } \\
\text { itive cocci, } \\
\text { ovoids }\end{array}$ \\
\hline $\begin{array}{l}\text { Typical growth } \\
\text { on solid nutrient } \\
\text { media }\end{array}$ & $\begin{array}{c}\text { Typical for the } \\
\text { species }\end{array}$ & $\begin{array}{c}\text { Typical for the } \\
\text { species }\end{array}$ & $\begin{array}{c}\text { Typical for the } \\
\text { species }\end{array}$ & $\begin{array}{c}\text { Typical for the } \\
\text { species }\end{array}$ \\
\hline
\end{tabular}


cells of a lyophilized culture of $P$. multocida was $1.4 \times 10^{4} \mathrm{CFU} / \mathrm{cm}^{3}, Y$. pseudotuberculosis - $1.8 \times 10^{4} \mathrm{CFU} / \mathrm{cm}^{3}, S$. typhimurium $1.9 \times 10^{5} \mathrm{CFU} / \mathrm{cm}^{3}$, S. aureus $-1.7 \times 10^{6} \mathrm{CFU} / \mathrm{cm}^{3}$, which is from baseline $0.09 \%, 0.013 \%, 0.016 \%$, and $0.05 \%$, respectively. Rehydrated cultures were inoculated into appropriate culture media (Table 4). After the appropriate incubation period in the studied cultures, the homogeneity of the population of microorganisms and the concentration of viable cells were determined. From daily broth cultures made sowings on the corresponding solid nutrient media. After the appropriate incubation period, the typical growth of inoculated cultures was determined. The studied populations of cultures had homogeneous cell morphology, during incubation on solid nutrient media formed typically for the species colonies. The results of determining the concentration of viable cells in microorganism populations on different culture media are shown in Table 4.

The obtained results indicate that the biomass of the studied cultures in the initial titer $\mathrm{x} \times 10^{9}$ was obtained by a single passage on different culture media. The highest productivity in recovered cultures was obtained with the use of BHIB, (HiMedia, India) (the concentration of live microbial cells in the experimental cultures was recorded in the range of 5.7-6.4 $\times 10^{9} \mathrm{CFU} /$ $\left.\mathrm{cm}^{3}\right)$. The productivity of $S$. typhimurium culture with the use of MPB and TSB was

\section{Concentration of viable cells in recovered cultures}

\begin{tabular}{|l|l|}
\hline \multicolumn{1}{|c|}{ Culture media } & Concentration of viable cells, CFU/cm \\
\hline \multicolumn{2}{|c|}{ Salmonella typhimurium } \\
\hline Meat-peptone broth & $2.1 \times 10^{9}$ \\
\hline Brain-hearth infusion broth & $6.0 \times 10^{9}$ \\
\hline Tryptone soya broth & $2.6 \times 10^{9}$ \\
\hline \multicolumn{2}{|c|}{ Yersinia pseudotuberculosis } \\
\hline Meat-peptone broth \\
\hline Brain-hearth infusion broth & $1.8 \times 10^{9}$ \\
\hline Tryptone soya broth & $5.7 \times 10^{9}$ \\
\hline \multicolumn{2}{|c|}{$2.1 \times 10^{9}$} \\
\hline $\begin{array}{l}\text { MPB culture media with the addition of 5\% } \% \\
\text { equine serum and 0.5\% glucose }\end{array}$ \\
\hline $\begin{array}{l}\text { MPB with the addition of 5\% bovine serum and } \\
0.5 \% \text { glucose }\end{array}$ & $1.5 \times 10^{9}$ \\
\hline Brain-hearth infusion broth & $1.1 \times 10^{9}$ \\
\hline Tryptone soya broth & $6.1 \times 10^{9}$ \\
\hline \multicolumn{2}{|c|}{ Staphylococcus aureus } \\
\hline $\begin{array}{l}\text { MPB culture media with the addition of 5\% } \\
\text { equine serum and 0.5\% glucose }\end{array}$ & $1.0 \times 10^{9}$ \\
\hline $\begin{array}{l}\text { MPB with the addition of 5\% bovine serum } \\
\text { and 0.5\% glucose }\end{array}$ & $2.3 \times 10^{9}$ \\
\hline Brain-hearth infusion broth & $2.0 \times 10^{9}$ \\
\hline Tryptone soya broth & $6.4 \times 10^{9}$ \\
\hline
\end{tabular}




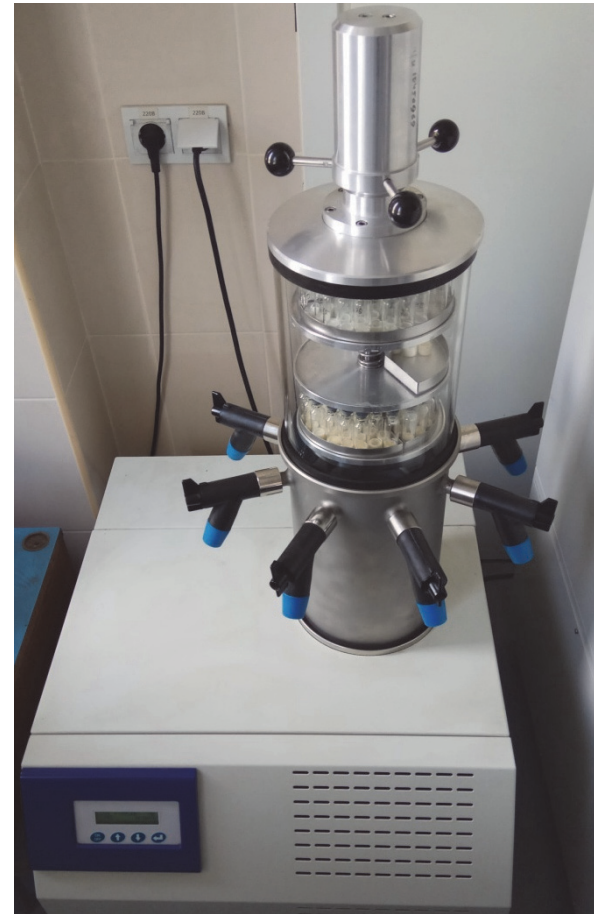

Fig. 4. The process of lyophilization

lower by 65 and $57 \%$, respectively. The productivity of $Y$. pseudotuberculosis culture with the use of BHIB and TSB was lower by 68 and $63 \%$, respectively. The productivity of $P$. multocida culture with the use of MPB with $5 \%$ equine serum and $0.5 \%$ glucose, $\mathrm{MPB}$ with $5 \%$ bovine serum and $0.5 \%$ glucose and TSB was lower by $75 \%, 82$, and $84 \%$, respectively. The productivity of $S$. aureus culture with the use of MPB with $5 \%$ equine serum and $0.5 \%$ glucose, MPB with 5\% bovine serum and $0.5 \%$ glucose, TSB was lower by $64 \%$, 69 , and $36 \%$ respectively.

\section{Conclusion and future perspectives}

1. It was found that in the process of sublimation and cryopreservation of Salmonella typhimurium, Pasteurella multocida, Yersinia pseudotu- berculosis, Staphylococcus aureus cultures, the loss of viable microbial cells was $99.91-99.987 \%$.

2 . The concentration of viable microbial cells in lyophilized cultures of Salmonella typhimurium, Pasteurella multocida, Yersinia pseudotuberculosis, Staphylococcus aureus was recorded in the range of $1.4 \times 10^{4}-1.7$ $\times 10^{6} \mathrm{CFU} / \mathrm{cm}^{3}$.

3. During a single passage on different culture media, the biomass of the studied cultures was obtained in the initial titer $\mathrm{x} \times 10^{9}$.

4. The highest productivity in recovered brain-hearth infusion broth manufactured by HiMedia, India (concentration of live microbial cells in experimental cultures was recorded in the range of 5.7-6.4 $\times 10^{9} \mathrm{CFU} / \mathrm{cm}^{3}$ ).

\section{References}

Akymenko, L. (2007). Pidtrymannia biotekhnolohichnykh kharakterystyk deponovanykh shtamiv - vazhlyva skladova yakosti imunobiolohichnykh preparativ. Naukovo-tekhnichnyi biuleten Derzhavnoho naukovo-doslidnoho kontrolnoho instytutu veterynarnykh preparativ ta kormovykh dobavok i Instytutu biolohii tvaryn, 8(3-4), 221-226.

Cherkasskiy, B., Minaev, V., \& Aleksandrova, N. (1988). Metodyi hraneniya kultur bakteriy roda Campylobacter. Aktualnyie voprosyi izucheniya kishechnyih infektsiy. Nalchik, 66-70.

Emtsova, T., Lavrova, L., \& Konstantinova, N. (1991). Vliyanie usloviy predvaritelnogo kultivirovaniya bakteriy na ih ustoychivost i strukturu kletki pri zamorazhivanii i liofilizatsii. Mikrobiologiya, 60(5), 879-889.

Holovko, A., Skrypnyk, H., Pinchuk, N., Hordiienko, O., \& Ordynska, D. (2004). Metodychni rekomendatsii po dovhotryvalomu zberezhenniu bakterii metodom sorbtsiino-kontaktnoho znevodnennia. Kyiv. 
Holovko, A., Ushkalov, A., Vygovska, L., \& Kovtun, V. (2015). Vyvchennia vplyvu zakhysnoho seredovyshcha z aerosylom u protsesi liofilizatsii ta zberihannia na doslidzhuvani kultury Yersinia spp. Naukovo-tekhnichnyi biuleten Instytutu biolohii tvaryn i Derzhavnoho naukovo-doslidnoho kontrolnoho instytutu vetpreparativ ta kormovykh dobavok,16(2), 188-193.

Hordiienko, O. (2018). Vykorystannia vysokodyspersnoho kremnezemu a-300 pry sublimatsii mikroorhanizmiv. Veterynarna biotekhnolohiia, 32(1), 80-84.

Hordiienko, O., Kudriavchenko,O., Shevchenko, P., \& Akymenko, L. (2007). Kinetyka znevodnennia materialu pry sublimatsii. Naukovo-tekhnichnyi biuleten Derzhavnoho naukovo-doslidnoho kontrolnoho instytutu veterynarnykh preparativ ta kormovykh dobavok i Instytutu biolohii tvaryn, 8(3-4), 221-226.

Hordiienko,O.I.,Postoienko, V.O., Kravetskyi,L.Y., \& Salhanska, O. O. (2011). Optymizatsiia parametriv stadii dosushuvannia protsesu liofilizatsii E. coli 0-55 pry vykorystanni modyfikovanykh zakhysnykh seredovyshch [Optimization of parameters of the drying stage of the lyophilization process of E. coli 0-55 using modified protective media]. Veterynarna medytsyna, (95), 51-53.

Kovtun, V.,Ushkalov, V., Vygovska, L., \&Machuskyi,O. (2013). Konstruiuvannia zakhysnoho seredovyshcha dlia liofilizatsii bakterii rodu Listeria. Veterynarna biotekhnolohiia: biulleten. Instytut veterynarnoi medytsyny NAAN, Derzhavnyi naukovo-kontrolnyi instytut biotekhnolohii i shtamiv mikroorhanizmiv, 22, 224-232.

Metodicheskie ukazaniya "Epidemiologicheskiy nadzor i profilaktika psevdotuberkuleza i kishechnogo iersinioza". (2009). Retrieved from http://docs.cntd.ru/document/1200070491

Osadchaja, A. I., Kudrjavcev, V. A., \& Safronova, L. A. (2002). Vlijanie nekotoryh faktorov na kriorezistentnost' i sohranenie zhiznesposobnosti pri liofilizacii kul'tur Bacillus subtilis. Biotehnologija, (3), 45.
Postoienko, V., Hordiienko, O., Ushkalov, V., ta in. (2011). Vidnovlennia vydovykh oznak liofilno vysushenykh shtamiv E. coli pry tryvalomu zberihanni: metod. Rekomendatsii. Derzhvetfitosluzhba Ukrainy, Derzh. nauk.-kontrol. In.-t biotekhnolohii i shtamiv mikroorhanizmiv. Kyiv, 12.

Romanko, M. (2010). Membranotropnyi vplyv nanochastynok aurumu ta argentumu na intensyvnist okysniuvalnykh protsesiv u klitynakh Escherichia za umov yikh liofilizatsii/rehidratatsii. Biolohiia tvaryn, 12(2), 460-473.

Romanko, M., Ushkalov, V., \& Holovko, A. (2006). Stres u mikroorhanizmiv ta virulentnist. Veterynarna biotekhnolohiia, 8, 222-241.

Romanko, M., \& Rieznichenko, L. (2012). Nanochastynky aurumu ta arhentumu yak potentsiini krioprotektory za dovhotryvaloho zberihannia vyrobnychykh shtamiv mikroorhanizmiv. Biotekhnolohiia, 5(5), 100-108.

Stehnii, B., Sikachyna, V., Plys, V., et all. (2009). Metodychni rekomendatsii z diahnostyky, profilaktyky ta zakhodiv borotby z pasterelozom (kholeroiu) ptytsi. Dnipropetrovsk.

Ushkalov, V., Salhanska, O., Vygovska, L., \& Postoienko, V. (2008). Doslidzhennia biolohichnykh vlastyvostei bakterii rodu Salmonella pry tryvalomu zberihanni u liofilnomu stani. Veterynarna biotekhnolohiia, 12, 276-283.

Ushkalov, V., \& Vygovska, L. (2009). Osoblyvosti dovhostrokovoho zberihannia bakteri vydu Listeria monocytogenes. Veterynarna medytsyna, 92, 503-505.

Vygovska, L., Ushkalov, V., Akymenko, L., Salhanska, O., \& Semko, K. (2007). Robota zi shtamamy mikroorhanizmiv u DNKIBShM. Veterynarna medytsyna Ukrainy, 12, 17-19.

Vyigovskaya, L., Ushkalov, V., \& Gordienko, O. (2008). Izuchenie vliyaniya liofilizatsii i usloviy kultivirovaniya na biologicheskie svoystva bakteriy roda Listeria. Problemyi profilaktiki i borbyi s osobo opasnyimi, ekzoticheskimi i maloizuchennyimi infektsionnyimi boleznyami zhivotnyih, 2, 235-239. 
В. О. Ушкалов, Л. М. Виговська, А. В. Ушкалов, С. О. Бояновський, А. В. Гранат, С. А. Терещенко, Л. О. Давидовська, Вішован. (2021). ДОСЛІДЖЕННЯ ЕФЕКТИВНОСТІ КУЛЬТУРАЛЬНИХ СЕРЕДОВИЩ ДЛЯ ВІДНОВЛЕННЯ ЛІОФІЛІЗОВАНИХ ПАТОГЕННИХ БАКТЕРІЙ. Ukrainian Journal of Veterinary Sciences, 12(1): 40-50, https://doi.org/10.31548/ujvs2021.01.005

Анотація. На сьогодні найбільш доцільним способом довготривалого зберігання більшості штамів мікроорганізмів у колекціях $\epsilon$ їх ліофілізація. Швидкість та якість відновлення біологічних властивостей ліофілізованих бактеріальних культур багато залежить від якості культуральних середовищ, що використовують з иією метою. Метою було дослідити ефективність культуральних середовищ для відновлення ліофілізованих патогенних бактерій.

у роботі використовували итами Salmonella typhimurium, Pasteurella multocida, Yersinia pseudotuberculosis, Staphylococcus aureus з колекції Української лабораторії якості і безпеки продукції АПК Національного університету біоресурсів і природокористування України. Для відновлення ліофілізованих бактеріальних культур використовували декілька варіантів культуральних середовищ: м ясо-пептонний бульйон (Фармактив, Україна) з додаванням 5\% сироватки крові коня та 0,5\% глюкози; мıясо-пептонний бульйон (Фармактив, Україна) з додаванням 5\% сироватки крові великої рогатої худоби ma 0,5 \% глюкози; серцево-мозковий бульйон (HiMedia, India) ma триптон-соєвий бульйон (HiMedia, India). В якості кріопротектора використовували захисне середовище Файбича. Встановлено, що в процесі сублімації та кріоконсервації культур Salmonella typhimurium, Pasteurella multocida, Yersinia pseudotuberculosis, Staphylococcus aureus втрати життєздатних мікробних клітин становили 99,91-99,98\%. Концентрацію життєздатних мікробних клітин у ліофілізованих культур Salmonella typhimurium, Pasteurella multocida, Yersinia pseudotuberculosis, Staphylococcus aureus реєстрували в межах $1,4 \times 10^{4}-1,7 \times 10^{6} \mathrm{kУO} / \mathrm{cm}^{3}$. За однократного пасажування на різних культуральних середовищах було отримано біомаси досліджуваних культур у вихідному титрі $x \times$ 109. Найвищу продуктивність у відновлених культур біло отримано за застосування серцево-мозкового бульйону виробництва компанії НiMedia, India (концентрацію живих

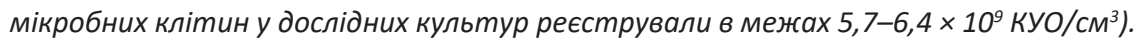

Ключові слова: Salmonella, Pasteurella, Yersinia, Staphylococcus, поживні середовища, ліорілізація 